A N N A L E S

UNIVERSITATIS M A RIAE CURIE-SKŁODOWSKA

LUBLIN - POLONIA

VOL. XXXIII, 1

SECTIO J

2020

Pedagogical University of Cracow. Institute of Educational Science

KATARZYNA JAGIELSKA

ORCID: 0000-0002-9953-5608

jagielska@up.krakow.pl

\title{
Attitudes of the Elderly Towards Old Age
}

Postawy osób starszych wobec starości

How to Quote this Paper: Jagielska, K. (2020). Attitudes of the Elderly Towards Old Age. Annales Universitatis Mariae Curie-Skłodowska. Sectio J, Paedagogia-Psychologia, 33(1), 165-175. DOI: http://dx.doi.org/10.17951/j.2020.33.1.165-175.

\section{SUMMARY}

Aging is one of the greatest challenges of the $21^{\text {st }}$ century. This situation has consequences for social, health, economic and educational policies. In the face of these changes, it is important for a person working with seniors to be well prepared for challenges at work. From this perspective, it is important to learn about the attitudes of seniors towards their own old age. It will help to understand the functioning of the individual in old age. An analysis of the literature on the subject indicates that the attitudes of other people towards seniors and the perception of their own old age affect how an individual ages and how he/she assesses his/her quality of life. Knowledge of attitudes towards old age can be used to plan activities for active aging. The article is a review and summarizes the state of knowledge about attitudes towards old age contained in the Polish literature on the subject. It also integrates existing knowledge about attitudes towards old age. The aim of the article was to present the most important concepts of attitudes towards old age and to indicate the area of application of this knowledge to social work practice (both its inclusion in curricula as well as accessibility for social workers). Taking into account the criterion of the review article, the focus was put on justifying the need to take up this subject in view of aging societies, providing a definitive definition of the concept of "attitude", its relation to the concept of attitudes towards old age, and the most important typologies of attitudes towards old age. The summary presents some practical conclusions for the practice of social work.

Keywords: old age; aging; attitude; types of attitudes towards old age 


\section{INTRODUCTION}

Poland's demographic threshold of old age was crossed in the second half of the 1960s. Since then, an ever faster increase in the proportion of old people in the society has been observed. In 1990, people aged 65 and over accounted for over $10.2 \%$ of the population, i.e. 3.8 million, while in 2018 the figure rose to over $17.5 \%$, i.e. 6.7 million (GUS, 2019). The phenomenon of an aging population is one of the most important changes of the $21^{\text {st }}$ century. This demographic phenomenon is of concern and is a huge challenge not only for social, health, economic and educational policies but also for social and health service employees and families directly involved in caring for the elderly.

Several phenomena affect the process of aging. Firstly, there is life expectancy, which is influenced by economic growth, improvement of living conditions, improvement of health conditions and technological progress, in particular in terms of medical diagnosis methods. Secondly, the post-war baby boom generation is entering their retirement age (the so-called baby boom effect). Thirdly, there is a decline in fertility rates (Szarota, 2010, p. 8). As Zofia Szarota notes:

(...) the change in customs is contributing to the aging of the population: emancipation, scholarisation, professional involvement of the female population who are increasingly implementing their own ambitious life plans and whose aspirations go beyond the standards of a good wife and a mother. They undertake educational and then professional effort, also to harbouring their own ambitions. (Szarota, 2010, p. 9)

These changes in family models go hand in hand with changes in morality. Multi-generational, traditional families are giving way to nuclear families (small, two-generational), with a small number of children, with late motherhood or to childless families (Szarota, 2010).

These changes influence the situation of the older generation, in particular to the organisation of care for the elderly, which is in need of systemic solutions. On the one hand, they should facilitate the organisation of daily life of families with older people under their care. On the other hand, emphasis should be placed on good preparation of social assistance and health care workers. Due to the need for assistance in this area, the number of employees in geriatric care should also be increased. Education also plays an important role here, as it should prepare younger generations, teaching them how to skillfully care for their seniors.

Another issue is old people's attitudes towards their own old age. Adaptation to life in old age is important for the perception of its quality, and also has an impact on what forms of activity will be undertaken.

The literature review by Anna E. Kornadt, Jelena S. Siebert and Hans-Werner Wahl (2019) shows that the attitudes of old age and old age condition the as- 
sessment of the quality of life and how we age. Views on aging can be divided into three categories: (1) age stereotypes (socially shared beliefs about the aging process and older people as a group), (2) subjective age (the age people feel like) and (3) self-assessment of the perception of aging (expectations and assessment of one's aging), i.e. attitude towards one's old age. The analysis of the texts leads to the following observations: attitudes towards own old age affect development processes and the activity of elderly (people with a positive attitude towards their old age show healthy behaviours, better health, and lower mortality, they also show better cognitive functioning and lower risk of dementia compared with people with a more negative attitude towards their own aging). Attitudes towards one's old age also influence the choice of the development goal and its implementation. It was pointed out that people who perceive old age as a time of activity, rest and pleasure, may want to remain socially active in old age and engage in more activities, whereas people with more negative attitudes towards old age and expectations regarding social life in old age can also act accordingly and limit their activity and social life. Attitudes towards old age also play a key role in selfregulation and self-preservation in old age.

The purpose of this article is to provide a review of the concept of attitudes of older people towards their own old age and to show practical implications for working with older people. The ability to recognize attitudes towards old age is very important in working with seniors and can significantly facilitate the understanding of older people, as well as help in effective work with seniors and preparation of appropriate programs of activating activities. In the frame of the article, the literature on the subject and the concepts of attitudes towards old age available in Poland were reviewed and analysed. This made it possible to show the most popular concepts, but also to indicate whether the literature containing this issue is available to social workers and carers of the elderly.

\section{DEFINITIONAL APPROACH TO ATTITUDES}

The term "attitude" is an ambiguous concept. It is worth quoting the definition of Gordon W. Allport (1929), according to whom "attitude" is an instruction to action, built by the integration of many specific responses of a similar type, but only those that exist as a general neural state, which when activated by a specific neural stimulus, elicits behaviour which is rather a function of disposition than an activating stimulus. It is important to remember this definition because it treats attitudes as broad, general (not simple and specific) behavioural conditioning. Attitudes are "mental and neural states of readiness, organised by experience, exerting a directional or dynamic effect on individuals' responses to all objects or situations with which they are associated" (quotation after Mądrzycki, 1997, p. 13). According to Stefan Nowak, "attitudes explain those human behaviours that are characterised by 
a certain persistence and modify the relationship between the behaviours and the situations that caused them" (quotation after Pilch, 2005, pp. 743-749).

Attitudes are also related to human values. According to William I. Thomas and Florian Znaniecki (1918, p. 27), "the process of individual consciousness that determines the actual or possible activity of an individual against the social world, the activity in any form being a bond between them, is understood as an attitude". According to their definition, attitudes, which are expressed in socially recognised norms of behaviour, also become social values (Fidelus, 2012, p. 96). The issue of attitudes towards old age is all the more important because it depends on how older people approach this period of life and what attitudes they adopt, whether they perceive it as beneficial and fulfilling. Will it be the next stage of life which can be filled with various activities? Will it be the time for rest and reflection or will it be the time for regret, anger and loss, the time for the adoption of claiming attitudes towards their environment, as a result of helplessness towards the inevitable transience? Old people either accept their own old age and, by accepting the passing of time, are able to adapt to the changes or assume attitudes of disapproval and withdrawal and become claimants.

The way one experiences old age depends on multiple factors, one of the most important being one's life story. The sources of old age attitudes should be tracked down to life experiences. Old age is a consequence of childhood, adolescence and adulthood (Czerniawska, 2000, p. 169).

Old age can turn out to be the most beautiful period of one's life if it is lived with dignity and wisely, in a sense of fulfilment and gratitude, but it can also be a time of sadness, loneliness and hopelessness when there is no sense of meaning and purpose in life. Positive attitudes towards old age are associated with growing experience of life wisdom and undertaking life-related life tasks (related to children and grandchildren). People with negative attitudes towards old age feel less motivated to be active and they care less about health and lifestyle. (Steuden, 2014, pp. 179-180)

To understand elderly people, one needs to look into their biographies, as in them hide the budding attitudes that are later adopted in old age. Life experiences, successes and failures are inseparable elements of people's everyday experiences. Old age is a time of reflection on the past. If in the past a senior was active, made his/her dreams come true and was successful, then in old age, he/she should also take up new challenges and be active in his/her old age. Therefore, unhappy biographies are hardly guarantees for joyful and peaceful old age.

\section{CONCEPTS OF ATTITUDES TOWARDS OLD AGE}

The perception of one's old age is influenced by many factors, which include: health, sense of meaning in life, the course of life biography, life experiences, lifestyle, attitudes towards one's old age, social and family relations, politics and 
social assistance (Kijak, Szarota, 2013, p. 86). Before presenting different classifications of attitude types, I will present the concept of human development in a full life cycle by Erik H. Erikson (1994). According to this concept, human maturation is a lifelong process, and adults mature by solving developmental crises throughout their entire lives. To understand the elderly in their old age, it is necessary to perceive them in the context of the whole history of their lives. Within his concept, Erikson distinguishes eight phases: the first phase, related to the acquisition of trust and especially to the breaking of the existential tension between trust and distrust, constitutes a basis for a "healthy personality"; the second phase is a struggle for autonomy; the third phase is an initiative phase; the fourth phase falls on the initial education period, being the time for identification with other people; the fifth phase is labeled as adolescence crisis and an identity search phase; the sixth phase includes early adulthood; the seventh phase, with its basic requirement being maturity to intimacy, is adulthood - it is dominated by the capacity for procreation, creativity and productivity (Szymański, 2000, pp. 51-54); the last phase is old age, which is a life balancing period - it is characterised by attitudes of internal integration in opposition to attitudes of bitterness, loss of hope and despair (after reaching the age of 60).

Erikson emphasizes that old age is a final stage of life, a time of reflection and assessment. Integrity appears together with a positive assessment of one's course of life, while despair is a result of a negative assessment of the past. It is also worth referring to the insights of Jerzy Modrzewski (2004, p. 2017), who states that in the last phase of life, renational (degrading) socialisation dominates, which is characterised by withdrawal from social life or loss of roles and positions, or limitation in the repertoire of roles. Wisdom manifested in understanding the inevitability of death and its acceptance guarantees success in the last phase of life (see Zych, Bartel, 1990, pp. 42-43; Erikson, 1995, 1997, 2002, 2004; Witkowski, 2000; Hill, 2010, pp. 54-58; Szarota, 2010, pp. 34-36). A positive course of this phase and the entire preceding developmental path lead to life satisfaction, whereas failure leads to despair, a sense of unfulfillment and lack of meaning of the life lived insofar (Szymański, 2000, p. 54).

According to Erikson's theory, positive aging depends on human psychosocial development. They obtain maturity by going through various developmental stages, whose correct course guarantees a happy old age. Thus, throughout our lives, we "develop" attitudes towards old age.

Henryk Zajączkowski maintains that depending on old people's state of health and attitudes towards their old age, we can isolate five groups. Group I is elderly people who need care because of their psychophysical condition. Group II consists of the elderly who have retained their physical and mental health, but are characterised by reduced life dynamics and reduced interest; some of this group remain cheerful and hardworking because they feel needed, while others cannot 
find their place in the new reality, which leads to breakdowns, withdrawal from life, resignation and waiting for death; their attitudes towards the environment become demanding and burdensome for the environment. Group III are seniors described as "great old people", positively related to old age, characterised by high social activity, use their life experience and skillfully organise their time, provide advice, are able to make use of their life experience. Group IV are sick people requiring constant care. Group V are seniors who are in good health, but due to reduced interests cannot find a place in their lives; they are mean and capricious (cf. Zych, Bartel, 1990, pp. 4-45; see Chabior, Fabiś, Wawrzyniak, 2014, pp. 33-34).

Theories of adaptation to old age can be divided into those that in their classification take into account the state of physical and mental health, as well as those that describe their psychosocial functioning, or those that take into account all these aspects.

One concept of old people's attitudes, based on psycho-social functioning, was developed by Clellan S. Ford. He adopted methods and forms of solving problems and overcoming old age crises as a basis for the theory. The adopted attitudes determining individuals' positive or negative psychosocial functioning. Accepting transience makes room for serene functioning in old age, while rebellion can be manifested by withdrawal, regression and isolation. According to C.S. Ford, the following types of mental attitudes can be distinguished:

- regression: it manifests itself in the form of enforcing assistance in everyday life, despite good health and lack of indications for care,

- escape: a form of escape, an attempt to negate a difficult life situation; such a form of escape may be, e.g., a change of residence,

- voluntary isolation from the environment: adopting a passive attitude towards reality and limited participation in social life,

- treacherous behaviour: an attitude that consists in the desire to gain a higher position and interest in one's surroundings,

- integration and adaptation: an attitude characterised by activity and commitment to social life, kindness and openness in social relations, the activities are undertaken regardless of health status (cf. Muchnicka-Djakow, 1984; Zych, Bartel, 1990; Szatur-Jaworska, Błędowski, Dzięgielewska, 2006; Kijak, Szarota, 2013).

In turn, Bernice L. Neugarten, Robert J. Havighurst and Sheldon S. Tobin (1968) propose eight patterns of attitudes to adapt to old age, depending on the type of personality, on social activity and on life satisfaction. However, before isolating the attitudes, they distinguished four main elderly personality types:

- integrated: characterised by high activity, cognitive functions and a high sense of life satisfaction, adaptation to old age,

- defensive: characterised by a sense of control of own behaviour, defensive attitudes in difficult situations, low adaptation to old age, 
- passive dependent: characterised by seeking dependence on others, seeking support, apathy, low adaptation to old age, and

- non-integrated (disintegrated): characterised by emotional disorders and cognitive disruption, low adaptation to old age.

These four personality types are divided into eight patterns, depending on activity and life satisfaction. They refer, as in the case of the concept by C.S. Ford, to psychosocial functioning and various forms of activity undertaken at the last stage of life (whether they undertake social and educational activities, they maintain relationships with friends, or adopt an attitude of isolation, passivity, addiction). This concept is an extension of the theory developed by C.S. Ford. The authors distinguish eight models of attitudes, based on human activity and their way of functioning in earlier stages of life:

1. Model A (Reorganiser) - people involved in a wide range of activities, representing the attitude of reorganising their own lives after retirement, maintaining high and diverse activity (different from the way they have lived so far). It is an attitude characterised by high life satisfaction.

2. Model B (Focused) - people focused on a moderate level of activity within their field of interest. These people are more selective in their initiatives than reorganisers and usually devote their energy to one or two activities, derive life satisfaction from what they like most, what they love. It is an attitude characterised by high life satisfaction.

3. Model C (Disengaged) - represents attitudes of withdrawal and characterises people with low levels of activity, but high life satisfaction, who derive satisfaction from watching life in progress. They feel calm and contented with the fact that they are not responsible for anything, devote their time to contemplation, reflection, and summary of their life.

4. Model D (Holding on) - a group of people for whom aging is a threat and who stay as long as possible within middle age patterns. They are characterised by maintaining their current activity at a medium or high level. These are people quite effective in their actions, whose life satisfaction persists as long as they manage to be very active and in good shape, people whose motto is: "I will work until I fall" or "As long as you have work, everything will be alright".

5. Model E (Constricted) - similar to B, it is characteristic of people contesting the process of aging, withdrawing from active life, narrowing their activities to specific roles. Activity is needed to maintain life satisfaction, but not always its choice results from the formation of interests.

6. Model F (Succorance seeking) - people characterised by an average level of activity and an average level of satisfaction with life, related to their need for help and cooperation from the environment. They expect care and affection from their loved ones, this being a prerequisite for choosing and maintaining 
their activity. Their satisfaction is conditioned by receiving help from their loved ones.

7. Model G (Apatethic) - people with medium or low life satisfaction. This includes a group of people who are apathetic, inactive. They have always presented this attitude. They have never expected much from life, have not given much and continue to assume such an attitude.

8. Model H (Disorganized) - refers to people who have low self-control and low life satisfaction, who require help and support from the environment (Neugarten et al., 1968, pp. 265-268; see also Muchnicka-Djakow, 1984; Czerniawska, 2000, pp. 128-129; Szatur-Jaworska et al. 2006).

Suzanne Reichard, Florine Livson and Paul Peterson (1962) present a different typology of attitudes towards old age. They distinguish five most common attitudes, taking into account old people's psychosocial functioning. Only one displays a positive approach to aging. Others are negative attitudes that manifest themselves in such activities as enforcing care, isolation or hostility. According to the authors, there are five personality types of adapting to old age:

1. The mature types, representing a constructive attitude, are characterised by life satisfaction, tolerance, a sense of humour, responsibility, undertaking activities for loved ones or people in need of help and support. People with this attitude are well adapted to their age and social situation.

2. The rocking-chair types, characterised by attitudes of dependence. They are passive, tired, seniors who like to rest, without aspirations, submissive, helpless, their attitude consists in demanding care, absorbing the attention of their loved ones or carers despite maintaining physical and mental fitness. They treat old age as freeing them from their duties.

3. The armoured types, characterised by defensive attitudes, i.e. people with a strong sense of duty, stiff attitudes to norms and principles, active, focused on external life, unable to talk about their own problems, afraid of their infirmity, declining the help of others, closing in their world, isolating themselves. These people stand in opposition to aging by means of excessive activity.

4. The angry types, representing attitudes of hostility directed at others - a negative attitude characterised by a conviction that others come to him only and exclusively because they want something in return and have bad intentions. Seniors falling under this category are aggressive towards the environment, dissatisfied with social relations, suspicious, blame others for their problems and mistakes, are pessimistic about old age, do not accept it. They adapt poorly.

5. The self-hating types display self-destructive attitudes, i.e. attitudes of inward-directed hostility, lack of acceptance of their old age, despair, simultaneous expectation and fear of death. The elderly falling under this category are passive, lonely, do not show initiative, have limited interests, display pes- 
simistic attitudes towards the future. It is a depressive type, poorly adapting to old age (Bromley, 1969, pp. 132-140; Szarota, 2004).

Each of these attitudes is the result of ways of life and life biographies. Among the typologies of attitudes towards old age, there is also Adam A. Zych's typology based on emotional and social conditions. These are:

- fear of old age and rebellion against aging,

- resignation and/or social and emotional isolation,

- sensible, cognitive and emotional acceptance of old age as a natural phase of human life,

- reflective attitude towards past life (Zych, Bartel, 1990, pp. 58-50).

The selection of typologies of attitudes of elderly people towards their own old age is meant to shed some light to facilitate research into the very topical problem of modern societies (see Halicka 2004).

\section{CONCLUSIONS}

Everyone perceives their old age differently, and they also adopt different adaptation strategies. This last, unavoidable stage of life is not always comfortable or desired. It is very often associated with loss of something: influence, power, health, intellectual ability or the loved ones. Old people are not always able to come to terms with it. Their perception of this last stage of life can be influenced by many factors, which can be divided into subjective, most often related to biographies, and objective, i.e. those that enable dignified and comfortable functioning within society. Depending on attitudes towards old age, seniors are either involved in social life, act for the benefit of the local community, develop interests, participate in various forms of education and enjoy active lifestyles, or slowly begin to withdraw from social life. They can be characterised by attitudes of isolation from the environment, of doubt and resentment in the context of their transience and the end of their lives. Aging is a challenge. It depends on biographies, medical condition, balance of achievements, experience and attitude towards old age, as well as on what makes old people tick during the last stage of their lives, and what attitudes they adopt. Old age brings about clear changes in many areas of life, but our attitude towards our old age will be influenced by our history and the ensuing consistency in our operational mode.

The presented review of the literature led to specify the most important attitudes towards one's own aging. A significant statement is that some of these important concepts are presented in materials dedicated to social workers, and that is why it is important to pay attention to their inclusion in the content of education of social workers, not only as part of social gerontology and psychology classes, but also in pedagogical and methodological subjects. An important implication for working with an elderly person is that knowledge of attitudes 
towards the mentee's own old age can make it easier to understand his behaviour, adjust the language of communication, and in particular facilitate setting development goals for a given individual and working on motivation to change. The aging process is favourable for people who are positive about old age. Positive attitudes give the opportunity to use the potential of older people to work as a volunteer for the elderly. In the case of people with negative attitudes towards their old age, resulting in, among others, withdrawal from life, isolation, a negative way of communication, it is worth considering the opportunity to work on motivation to change, support in finding the meaning and purpose of life in old age. Knowledge of attitudes towards old age gives broad possibilities in planning work with seniors, preparation of appropriate work programs and activation of seniors.

\section{REFERENCES}

Allport, G.W. (1929). The composition of political attitudes. American Journal of Sociology, 35(2), 220-238. DOI: https://doi.org/10.1086/214980

Bromley, D.B. (1969). Psychologia starzenia się. Warszawa: PWN.

Chabior, A., Fabiś, A., Wawrzyniak, J. (2014). Starzenie się i starość w perspektywie pracy socjalnej. Warszawa: Centrum Rozwoju Zasobów Ludzkich.

Czerniawska, O. (2000). Drogi i bezdroża andragogiki i gerontologii. Szkice i rozprawy. Łódź: Wydawnictwo WSHE.

Erikson, E.H. (1994). The Life Cycle Completed. New York, London: W.W. Norton \& Company.

Erikson, E.H. (1995). Play and actuality. In: A.I. Brzezińska, T. Czub, G. Lutomski, B. Smykowski (red.), Dziecko w zabawie i świecie języka (pp. 232-269). Poznań: Wydawnictwo Zysk i S-ka.

Erikson, E.H. (1997). Dzieciństwo i społeczeństwo. Poznań: Dom Wydawniczy Rebis.

Erikson, E.H. (2002). Dopetniony cykl życia. Poznań: Dom Wydawniczy Rebis.

Erikson, E.H. (2004). Tożsamość a cykl życia. Poznań: Wydawnictwo Zysk i S-ka.

Fidelus, A. (2012). Postawy społeczne jako element kapitału społecznego a proces readaptacji skazanych. Forum Pedagogiczne, (1), 87-124.

GUS (2019). Sytuacja demograficzna Polski do 2018 r. Tworzenie i rozpad rodzin. Retrieved from: https://stat.gov.pl/obszary-tematyczne/ludnosc/ludnosc/sytuacja-demograficzna-polski-do2018-roku-tworzenie-i-rozpad-rodzin,33,2.html (access: 17.06.2019).

Halicka, M. (2004). Satysfakcja życiowa ludzi starych. Studium teoretyczno-empiryczne. Białystok: Wydawnictwo Akademii Medycznej.

Hill, R.D. (2010). Pozytywne starzenie się. Młodzi duchem w jesieni życia. Warszawa: MT Biznes.

Kijak, R., Szarota, Z. (2013). Starość. Między diagnozą a dziataniem. Warszawa: Centrum Rozwoju Zasobów Ludzkich.

Kornadt, A.E., Siebert, J.S., Wahl, H.-W. (2019) The interplay of personality and attitudes toward own aging across two decades of later life. PLoS ONE, 14(10). e0223622.

DOI: https://doi.org/10.1371/journal.pone.0223622

Mądrzycki, T. (1997). Psychologiczne prawidtowości ksztaltowania się postaw. Warszawa: WSiP.

Modrzewski, J. (2004). Socjalizacja i uczestnictwo społeczne. Studium socjopedagogiczne. Poznań: Wydawnictwo Naukowe UAM.

Muchnicka-Djakow, I. (1984). Czas wolny w klubie seniora. Warszawa: Instytut Wydawniczy Związków Zawodowych. 
Neugarten, B.L., Havighurst, R.J., Tobin, S.S. (1968). Personality and patterns of aging. In: B.L. Neugarten (ed.), Middle Age and Aging: A Reader in Social Psychology (pp. 173-174). Chicago: University of Chicago Press.

Pilch, T. (red.). (2005). Encyklopedia pedagogiczna XXI wieku (T. 4). Warszawa: Wydawnictwo Akademickie „Żak”.

Reichard, S., Livson, F., Peterson, P. (1962). Aging and Personality. New York: John Wiley and Sons.

Steuden, S. (2014). Psychologia starzenia się i starości. Warszawa: Wydawnictwo PWN.

Szarota, Z. (2004). Gerontologia społeczna i oświatowa. Zarys problematyki. Kraków: Wydawnictwo Naukowe Akademii Pedagogicznej.

Szarota, Z. (2010). Starzenie się i starość w wymiarze instytucjonalnego wsparcia. Kraków: Wydawnictwo Naukowe Uniwersytetu Pedagogicznego.

Szatur-Jaworska, B., Błędowski, P., Dzięgielewska, M. (2006). Podstawy gerontologii społecznej. Warszawa: Oficyna Wydawnicza Aspra-Jr.

Szymański, M.J. (2000). Studia $i$ szkice z socjologii edukacji. Warszawa: Instytut Badań Edukacyjnych.

Thomas, W.J., Znaniecki, F. (1918). Polish Peasant in Europe and America. Boston: Richard G. Badger, The Gorham Press.

Witkowski, L. (2000). Edukacja i humanistyka. Nowe konteksty humanistyczne dla nowoczesnych nauczycieli. Warszawa: Instytut Badań Edukacyjnych.

Zych, A.A., Bartel, R. (1990). Sytuacja życiowa ludzi $w$ podeszlym wieku $w$ Polsce $i$ w Republice Federalnej Niemiec. Kielce: Wydawnictwo Wyższej Szkoły Pedagogicznej im. Jana Kochanowskiego.

\section{STRESZCZENIE}

Starzenie się społeczeństw jest jednym z największych wyzwań XXI w. Sytuacja ta niesie za sobą konsekwencje dla polityki społecznej, zdrowotnej, gospodarczej i edukacyjnej. W obliczu zachodzących zmian ważne jest dobre przygotowanie do pracy osób pracujących z seniorami. Z tej perspektywy istotne jest zapoznanie się z postawami seniorów wobec własnej starości. Pomogą one zrozumieć funkcjonowanie jednostki w starości. Analiza literatury przedmiotu wskazuje, że postawy innych osób wobec seniorów oraz sposób postrzegania własnej starości wpływają na to, jak jednostka się starzeje i jak ocenia jakość swojego życia. Znajomość postaw wobec starości można wykorzystać do planowania działań na rzecz aktywnego starzenia się. Artykuł ma charakter przeglądowy i stanowi podsumowanie wiedzy na temat postaw wobec starości zawartej w polskiej literaturze przedmiotu oraz integruje dotychczasową wiedzę na temat postaw wobec starości. Celem opracowania było przybliżenie najważniejszych koncepcji postaw wobec starości oraz wskazanie obszaru zastosowania tej wiedzy do praktyki pracy socjalnej (zarówno uwzględnienie jej w programach nauczania, jak i udostępnienie pracownikom socjalnym). Uwzględniając kryterium przeglądowości, skoncentrowano się na: uzasadnieniu konieczności podjęcia tej tematyki z uwagi na starzejące się społeczeństwa, podaniu definicyjnego ujęcia pojęcia „postawa”, odniesieniu się do koncepcji postaw wobec starości. Ponadto przedstawiono najważniejsze typologie postaw wobec starości. W podsumowaniu zamieszczono kilka praktycznych wniosków dotyczących praktyki pracy socjalnej.

Slowa kluczowe: starość; starzenie się; postawy; typy postaw wobec starości 